\title{
SLAUGHTER VALUE OF POLISH LANDRACE FATTENERS FROM FARMS IN CENTRAL-EASTERN POLAND
}

\author{
Department of Animal Breeding, Warsaw University of Life Sciences, Poland \\ ${ }^{1}$ Faculty of Agrobioengineering and Animal Husbandry, Siedlce University of Natural Sciences \\ and Humanities, Poland
}

\begin{abstract}
The aim of this work is to evaluate the slaughter value of porkers from individual farms in the same producer group located in central-eastern Poland. The research was conducted on 322 fatteners of the Polish Landrace breed. The research material was classified according to two research factors: supplier and season of the year. One group of fatteners was slaughtered in the autumn (September-October) and the second in spring (April-May). The studied population of fatteners was characterized by high meatiness at an average level of $58 \%$ and average hot carcass weight of $89.99 \mathrm{~kg}$. All carcasses were classified as the highest classes of the SEUROP system: $29.81 \%$ as class $\mathrm{S}, 51.86 \%$ as class $E$ and $18.32 \%$ as class $U$. A statistically significant influence of supplier was found for hot carcass weight, thickness of the longissimus dorsi muscle at $M_{1}$, and slaughtering efficiency. A statistically significant influence of slaughtering season on hot carcass weight and back fat thickness at points $S_{1}$ and $S_{2}$ was also found. Pigs slaughtered in spring were found to have a lower hot carcass weight and thinner back fat than those slaughtered in autumn. The interaction between supplier and slaughtering season was found to be statistically significant for hot carcass weight, meatiness, thickness of the longissimus dorsi at $\mathrm{M}_{2}$, and thickness of back fat measured at $S_{1}$. The obtained research results indicate the high slaughter value of porkers kept in individual farms within the same producer group, and that the pork obtained from these pigs meets the requirements set by the meat industry and consumers.
\end{abstract}

Key words: fatteners, supplier, season, meatiness, hot carcass weight.

\section{INTRODUCTION}

The quality of domestic pork raw material has been the subject of interest for both scientists and technologists working for the meat industry for over two decades (Różycki 1998; Grześkowiak 1999; Strzelecki et al. 2001; Koćwin-Podsiadła et al. 2004). This is mainly due to the preferences and requirements of consumers who have turned their attention towards from very lean meat (low intramuscular fat results in meat and meat products with high sensory qualities (Wood et al. 1994; Andersen et al. 2005; Vandendriessche 2008). Many years of work from Polish scientists, breeders and technologists has improved the production and processing of pork and resulted in a significant increase in the meat content of pig carcasses and a reduction in their fatness (Różycki 1998; Blicharski et al. 2004; Koćwin-Podsiadła et al. 2004; Lisiak and Borzuta 2008). The need for systematic improvement in meat (annually about 1\%)

Corresponding author: Marcin Gołębiewski, Department of Animal Breeding, Warsaw University of Life Sciences, Ciszewskiego 8, 02-787 Warszawa, Poland, e-mail: marcin_golebiewski@sggw.pl, ORCID: 0000-0003-0645-433X. 
and an increase in the slaughter value of porkers was caused by the introduction and legal sanctioning in 1993 of the objective classification of pig carcasses according to the SEUROP system and rewarding pig producers for meatiness (Dumas and Dhorne 1998; Borzuta 1999; Lisiak et al. 2005; Florek et al. 2006). In addition to meatiness, the weight of slaughtered fatteners also affects the slaughter value. The domestic meat industry prefers slaughter with a higher carcass weight, while maintaining high meatiness (55-58\%). Meat from light carcasses is characterized by higher post-mortem meatiness, but it has limited processing usefulness. In Poland, pork meatiness has increased at the same time as the hot carcass weight of pigs slaughtered in meat processing plants. From 2012-2017, the meatiness in carcasses stabilized at a high level (56.5-57.7\%) and so did the hot carcass weight (90-92.5 kg). This weight meets the requirements of the domestic meat industry (Lisiak et al. 2005; GUS 2017). Bearing in mind the above, there is a need for a detailed analysis of pig slaughter raw material from smaller individual farms within the same producer group.

The aim of the study is to evaluate the slaughter value of fatteners, depending on the supplier and the season of the year, from individual farms located in central-eastern Poland.

\section{MATERIAL AND METHODS}

The research was conducted on 322 fatteners of the Polish Landrace breed. The animals came from three farms $(A, B, C)$ located in central-eastern Poland, associated with the same producer group. The research material was grouped according to two research factors: supplier and season of the year. The first research group of fatteners was slaughtered in the autumn (from September to October), the second group in the spring (from April to May). In the experiment, the same share of gilts and hogs were taken for each supplier and season. Due to this, gender was eliminated as a factor that could have a significant impact on the slaughter value of fatteners. During the rearing period, the animals were provided with very similar living and feeding conditions. Pigs were fed with mixtures prepared from cereals from their own farm (30\% triticale meal, $60 \%$ barley grits) and high protein concentrate. Animals were slaughtered using gas stagnation (carbon dioxide) in the same meat factory located $20 \mathrm{~km}$ from the farms. Slaughtering was done after a short rest of the animals according to typical technology used in the meat factory. After completing the procedures typical for a meat factory, the evaluation of carcasses was carried out using Ultra-Fom 300 apparatus (SFK Technology) in the following areas:

- percentage meat content in the carcass (meatiness),

- thickness of the longissimus dorsi (LD) muscle after the last rib at a distance of $7 \mathrm{~cm}$ from the intersection line of carcasses cut into half-carcasses $\left(\mathrm{M}_{1}\right)$,

- thickness of the LD muscle between the 3rd and 4th ribs counted from the end $\left(M_{2}\right)$,

- thickness of the back fat after the last rib at a distance of $7 \mathrm{~cm}$ from the intersection line of carcasses cut into half-carcasses $\left(\mathrm{S}_{1}\right)$,

- thickness of the back fat between the 3rd and 4th ribs counted from the end $\left(S_{2}\right)$.

The hot carcass weight was also established on the weighing scales within 35 minutes after slaughter. The results were directly recorded by a computer connected to the Ultra-Fom 300 apparatus with an accuracy of $0.1 \mathrm{~kg}$.

The obtained results were analyzed using the statistical package STATISTICA 12.5 PL (Stat Soft, Tulusa, GK, USA). The influence of supplier (A, B, C), season (autumn, spring) and their interaction (supplier $x$ season) on the results was estimated using a two-factor analysis 
of variance in a non-orthogonal system according to the following line model. The level of significance of differences between means was verified using the NIR test (Luszniewicz and Słaby 2001).

\section{RESULTS AND DISCUSSION}

The population of Polish Landrace fatteners analyzed in this study (322 pigs) had an average carcass meatiness level of $58.11 \pm 3.01 \%$, with a low coefficient of variation $-5.18 \%$ (Table 1). The high meat content of the tested pigs was reflected in the SEUROP classification, as all carcasses were classified into the highest classifications of meatiness. $29.81 \%$ of carcasses were classified as $\mathrm{S}, 51.86 \%$ carcasses classified as $E$, and $18.32 \%$ carcasses as $U$ (Fig.1).

Table 1. General traits of the research material $(n=322)$

\begin{tabular}{lccc}
\multicolumn{1}{c}{ Trait } & $\bar{X}$ & SD & V \\
\hline Hot carcass weight [kg] & 89.99 & 10.40 & 11.60 \\
\hline Meatiness [\%] & 58.11 & 3.01 & 5.18 \\
\hline $\mathrm{S}_{1}[\mathrm{~mm}]$ & 15.91 & 4.21 & 26.46 \\
\hline $\mathrm{S}_{2}[\mathrm{~mm}]$ & 14.57 & 3.86 & 26.49 \\
\hline $\mathrm{M}_{1}[\mathrm{~mm}]$ & 59.29 & 5.94 & 10.01 \\
\hline $\mathrm{M}_{2}[\mathrm{~mm}]$ & 59.79 & 5.39 & 9.01 \\
\hline
\end{tabular}

$\bar{X}$ - arithmetic mean, SD - standard deviation, $V$ - coefficient of variation.
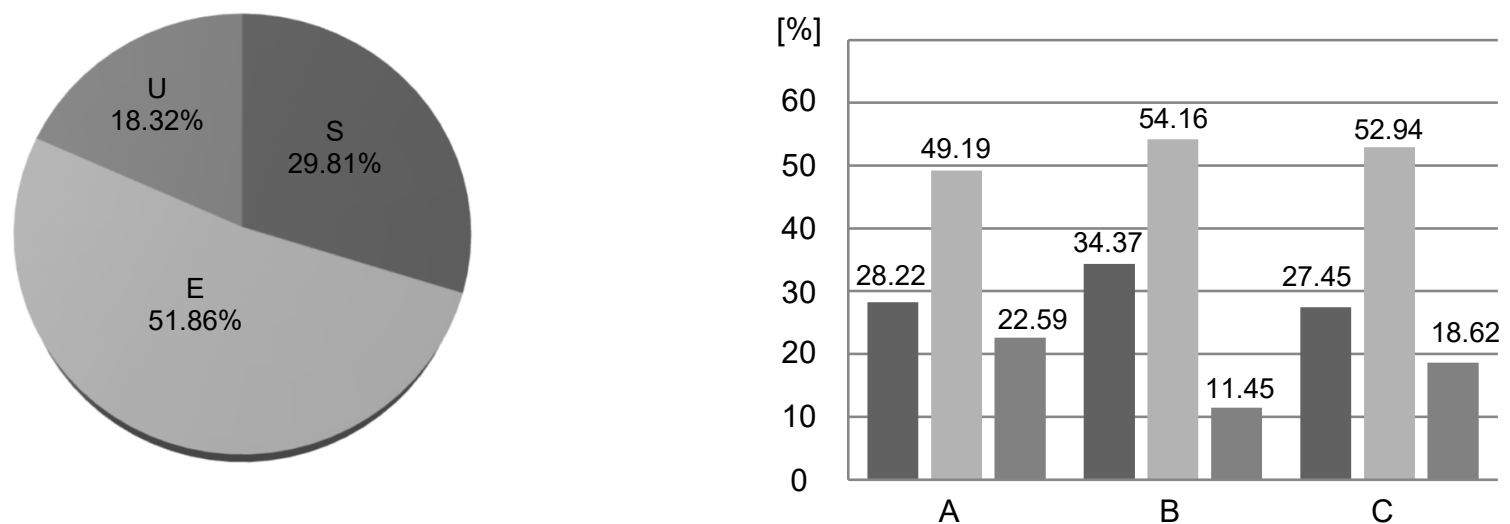

$\square \mathrm{S} \square \mathrm{E}$

Fig. 1. SEUROP classes of the research material $(n=322)$

S, E, U - classes in SEUROP classification.
Fig. 2. SEUROP classes for each supplier A, B, C - supplier.

$\mathrm{S}, \mathrm{E}, \mathrm{U}$ - classes in SEUROP classification.

The average meatiness noted in this research was higher (by more than 1\%) compared to the average meatiness of fatteners in 2016, which was $57 \%$ (Lisiak et al. 2016). Back fat thickness measured at both $S_{1}$ and $S_{2}$ were characterized by high variability expressed 
in the coefficient of variability, i.e.: respectively $26.46 \%$ with an average thickness of $15.91 \mathrm{~mm}$ for $S_{1}$ and $26.49 \%$ with an average thickness of $14.57 \mathrm{~mm}$ for $S_{2}$ was $10 \%$ and average thickness $59.29 \mathrm{~mm}$, while at $\mathrm{M}_{2}$, the coefficient of variation was $9 \%$ and average thickness $59.79 \mathrm{~mm}$ (Table 1).

In a study conducted by Antosik and Koćwin-Podsiadła (2010) on 2851 fatteners from mass populations, the average thickness of back fat was $13.00 \mathrm{~mm}$ at $S_{1}, 12.2 \mathrm{~mm}$ at $S_{2}$, and average LD muscle thickness around $61 \mathrm{~mm}$ at $\mathrm{M}_{1}$. In turn, Zybert et al. (2015) in their analysis of 9000 fatteners from mass populations, recorded an average thickness of back fat at points $S_{1}$ and $S_{2}$ as respectively $15.3 \mathrm{~mm}$ and $15.32 \mathrm{~mm}$ and an average LD thickness at points $M_{1}$ and $\mathrm{M}_{2}$ as respectively $58.22 \mathrm{~mm}$ and $57.75 \mathrm{~mm}$. In summary, in our study, the thickness of the LD muscle, i.e. a feature closely related to musculature, took intermediate values between the studies by Antosik and Koćwin (2010) and Zybert et al. (2015). The first authors obtained a higher thickness of the LD muscle and the second a lower compared to our study.

In this research, slaughtering efficiency was $78.19 \pm 7.14 \%$ with a coefficient of variation of $9.13 \%$. This is consistent with the slaughtering efficiency found in other studies, which ranges from 75-85\% (Weatherup et al. 1998; Zybert et al. 2001; Koćwin-Podsiadła et al. 2004).

Table 2. Influence of the research factors (supplier and season) on traits of the research material

\begin{tabular}{|c|c|c|c|}
\hline \multirow{2}{*}{ Trait } & \multicolumn{2}{|c|}{ Research factor } & \multirow{2}{*}{$\begin{array}{l}\text { Interaction (supplier } x \\
\text { season of the year) }\end{array}$} \\
\hline & supplier & season of the year & \\
\hline Hot carcass weight [kg] & $\underset{* *}{46.37}$ & $\underset{* *}{57.61}$ & $\underset{* *}{13.39}$ \\
\hline Meatiness [\%] & $\begin{array}{l}1.0 \\
\text { ns. }\end{array}$ & $\begin{array}{l}3.0 \\
\text { ns. }\end{array}$ & $\underset{*}{4.80}$ \\
\hline $\mathrm{S}_{1}[\mathrm{~mm}]$ & $\begin{array}{l}0.56 \\
\text { ns. }\end{array}$ & $\begin{array}{c}8.09 \\
*\end{array}$ & $\begin{array}{l}2.12 \\
\text { ns. }\end{array}$ \\
\hline $\mathrm{S}_{2}[\mathrm{~mm}]$ & $\begin{array}{l}1.57 \\
\text { ns. }\end{array}$ & $\underset{*}{7.79}$ & $\underset{*}{6.75}$ \\
\hline $\mathrm{M}_{1}[\mathrm{~mm}]$ & $\underset{*}{5.04}$ & $\begin{array}{l}1.10 \\
\text { ns. }\end{array}$ & $\begin{array}{l}3.01 \\
\text { ns. }\end{array}$ \\
\hline $\mathrm{M}_{2}[\mathrm{~mm}]$ & $\begin{array}{l}1.18 \\
\text { ns. }\end{array}$ & $\begin{array}{l}0.61 \\
\text { ns. }\end{array}$ & $\begin{array}{c}3.83 \\
*\end{array}$ \\
\hline Slaughter value [\%] & $\begin{array}{c}7.64 \\
* \\
\end{array}$ & $\begin{array}{l}1.15 \\
\text { ns. }\end{array}$ & $\begin{array}{l}1.71 \\
\text { ns. }\end{array}$ \\
\hline
\end{tabular}

${ }^{* *}$ statistically significant $p \leq 0.01,{ }^{*}$ statistically significant $p \leq 0.05$, ns. - not statistically significant.

The two-factor analysis of variance in a non-orthogonal system showed a statistically significant (at $p \leq 0.05$ ) or highly statistically significant (at $p \leq 0.01)$ interaction between the first research factor (the supplier) and the hot carcass weight, LD muscle thickness measured at $M_{1}$ and slaughtering efficiency. The relationship between the second research factor (season) and the hot carcass weight and back fat thickness at $S_{1}$ and $S_{2}$ was found to be significant at $p \leq 0.01$ and $p \leq 0.05$, respectively. The interaction between the two research factors (supplier and season) was found to have a significant influence on hot carcass weight, meatiness, back fat thickness and LD muscle thickness measured at point $2\left(S_{2}\right.$ and $\left.M_{2}\right)$ (Table 2). When analyzing each supplier separately, there was no statistically significant difference in the meatiness of the carcass from each supplier. The highest meatiness was found in carcasses from supplier B $(58.32 \pm 2.83 \%)$, then supplier $A(57.77 \pm 3.12 \%)$ and finally 
supplier C $(57.99 \pm 3.00 \%)$ (Table 3$)$. The SEUROP classes for carcasses from each supplier are a reflection of the above-described trend. Supplier $B$ had the largest percentage of carcasses with the highest meatiness (classified as $S$ ) and the lowest percentage of carcasses in the $U$ class (Fig. 2). Group A had a statistically significantly lower LD muscle thickness measured at point $M_{1}$ by $2.5 \mathrm{~mm}(58.21 \pm 6.59 \mathrm{~mm}$ compared to $60.67 \pm 5.30 \mathrm{~mm})$ in relation to group $B$. The LD muscle thickness at $M_{1}$ in group $C$ fell between the values from groups $A$ and $B(59.30 \pm 5.43 \mathrm{~mm})$. Hot carcass weight was found to differ significantly among suppliers. Group B had the lowest hot carcass weight of $84.03 \pm 7.44 \mathrm{~kg}$, then group $C$ at $89.23 \mathrm{~kg} \pm 9.70 \mathrm{~kg}$ followed by group A at $95.13 \pm 10.31 \mathrm{~kg}$ (Table 3).

Table 3. Influence of supplier on traits of the research material

\begin{tabular}{|c|c|c|c|}
\hline \multirow[b]{2}{*}{ Trait } & \multicolumn{3}{|c|}{ Supplier } \\
\hline & $\begin{array}{c}A \\
n=124\end{array}$ & $\begin{array}{c}B \\
n=96\end{array}$ & $\begin{array}{c}C \\
n=102\end{array}$ \\
\hline Hot carcass weight [kg] & $\begin{array}{r}95.13 \mathrm{C} \\
\pm 10.31 \\
\end{array}$ & $\begin{array}{r}84.03 \mathrm{~A} \\
\pm 7.44 \\
\end{array}$ & $\begin{array}{r}89.23 \mathrm{~B} \\
\pm 9.70 \\
\end{array}$ \\
\hline Meatiness [\%] & $\begin{array}{r}57.77 \\
\pm 3.12 \\
\end{array}$ & $\begin{array}{r}58.32 \\
\pm 2.83 \\
\end{array}$ & $\begin{array}{r}57.99 \\
\pm 3.00 \\
\end{array}$ \\
\hline $\mathrm{S}_{1}[\mathrm{~mm}]$ & $\begin{array}{r}16.20 \\
\pm 4.70 \\
\end{array}$ & $\begin{array}{r}15.61 \\
\pm 3.91 \\
\end{array}$ & $\begin{array}{r}15.81 \\
\pm 3.86 \\
\end{array}$ \\
\hline $\mathrm{S}_{2}[\mathrm{~mm}]$ & $\begin{array}{r}14.34 \\
\pm 3.76 \\
\end{array}$ & $\begin{array}{r}14.28 \\
\pm 3.91 \\
\end{array}$ & $\begin{array}{r}15.13 \\
\pm 3.90 \\
\end{array}$ \\
\hline $\mathrm{M}_{1}[\mathrm{~mm}]$ & $\begin{array}{r}58.21 \mathrm{~b} \\
\pm 6.59 \\
\end{array}$ & $\begin{array}{r}60.67 a \\
\pm 5.30 \\
\end{array}$ & $\begin{array}{r}59.30 \mathrm{ab} \\
\pm 5.43 \\
\end{array}$ \\
\hline $\mathrm{M}_{2}[\mathrm{~mm}]$ & $\begin{array}{r}59.28 \\
\pm 5.96 \\
\end{array}$ & $\begin{array}{r}60.29 \\
\pm 4.81 \\
\end{array}$ & $\begin{array}{r}59.94 \\
\pm 5.17 \\
\end{array}$ \\
\hline Slaughter value $[\%]$ & $\begin{array}{r}76.21 \mathrm{~b} \\
\pm 7.15 \\
\end{array}$ & $\begin{array}{r}79.61 \mathrm{a} \\
\pm 7.29 \\
\end{array}$ & $\begin{array}{r}79.08 \mathrm{~b} \\
\pm 6.49 \\
\end{array}$ \\
\hline
\end{tabular}

$A B C$ - average value between groups differs significantly statistically $p \leq 0.01$.

$a b-$ average value between groups differs significantly statistically $p \leq 0.05$.

\pm- standard deviation (SD).

This study noted a widespread tendency that an increase in hot carcass weight was accompanied by a decrease in meatiness and an increase in thickness of back fat. The above trend has also been found by many other researchers (Łyczyński et al. 2000; Zybert et al. 2001, 2005; Antosik and Koćwin-Podsiadła 2010; Antosik et al. 2010). In the studies by Antosik and Koćwin-Podsiadła (2010) conducted on mass populations of pigs, it was shown that an increase in hot carcass weight by $10 \mathrm{~kg}$ (from $80 \mathrm{~kg}$ to $90 \mathrm{~kg}$ ) contributed to a decrease in meatiness in the carcass by $2.8 \%$. Zybert et al. (2001), in a study on fatteners, found that a carcass weighing over $85 \mathrm{~kg}$ contributed to a reduction in meatiness by $4.3 \%$. However, for lightweight pigs (hot carcass weight up to $75 \mathrm{~kg}$ ), no loss of meatiness was noted. Similarly, to the results quoted above, Łyczyński et al. (2000) observed that fatteners whose carcass weight was higher than $90 \mathrm{~kg}$ had a statistically significantly lower meatiness and higher thickness of back fat compared to those whose weight was lower than $90 \mathrm{~kg}$. Examining the influence of the second research factor (season of the year) on the traits of the research material statistically confirmed differences for hot carcass weight and back fat thickness at $S_{1}$ and $S_{2}$. Pigs slaughtered in spring (regardless of the supplier) were characterized by a lower hot carcass weight compared to those slaughtered in autumn by about $7.5 \mathrm{~kg}(86.09 \pm 8.45 \mathrm{~kg}$ compared to $93.58 \pm 10.73 \mathrm{~kg}$ ) and lower back fat thickness at point $\mathrm{S}_{1}$ by approx. $1.30 \mathrm{~mm}$ $(15.23 \pm 4.10 \mathrm{~mm}$ compared to $16.52 \pm 4.29 \mathrm{~mm})$ and at point $\mathrm{S}_{2}$ by approx. $1.02 \mathrm{~mm}$ 
(14.04 $\pm 3.85 \mathrm{~mm}$ compared to $15.06 \pm 3.80 \mathrm{~mm}$ ). The season did not provide a statistically significant difference in meatiness. However, a tendency was noted that meatiness was $1 \%$ higher in fatteners slaughtered in spring, i.e. fatteners about $7.5 \mathrm{~kg}$ lighter that fatteners slaughtered in autumn (Table 4).

Table 4. Influence of season of the year on traits of the research material

\begin{tabular}{|c|c|c|}
\hline \multirow[b]{2}{*}{ Trait } & \multicolumn{2}{|c|}{ Season of the year } \\
\hline & $\begin{array}{l}\text { autumn } \\
\mathrm{n}=168\end{array}$ & $\begin{array}{c}\text { spring } \\
\mathrm{n}=154\end{array}$ \\
\hline Hot carcass weight [kg] & $\begin{array}{r}93.58 \mathrm{~B} \\
\pm 10.73\end{array}$ & $\begin{array}{r}86.09 \mathrm{~A} \\
\pm 8.45\end{array}$ \\
\hline Meatiness [\%] & $\begin{array}{r}57.58 \\
\pm 2.94\end{array}$ & $\begin{array}{r}58.47 \\
\pm 3.01\end{array}$ \\
\hline $\mathrm{S}_{1}[\mathrm{~mm}]$ & $\begin{array}{r}16.52 \mathrm{~b} \\
\pm 4.29\end{array}$ & $\begin{array}{r}15.23 a \\
\pm 4.10\end{array}$ \\
\hline $\mathrm{S}_{2}[\mathrm{~mm}]$ & $\begin{array}{r}15.06 \mathrm{~b} \\
\pm 3.80\end{array}$ & $\begin{array}{r}14.04 a \\
\pm 3.85\end{array}$ \\
\hline $\mathrm{M}_{1}[\mathrm{~mm}]$ & $\begin{array}{r}59.01 \\
\pm 5.58\end{array}$ & $\begin{array}{r}59.60 \\
\pm 6.31\end{array}$ \\
\hline $\mathrm{M}_{2}[\mathrm{~mm}]$ & $\begin{array}{r}59.62 \\
\pm 5.14\end{array}$ & $\begin{array}{r}59.98 \\
\pm 5.67\end{array}$ \\
\hline Slaughter value [\%] & $\begin{array}{r}77.68 \\
\pm 7.04\end{array}$ & $\begin{array}{r}78.61 \\
\pm 7.26\end{array}$ \\
\hline
\end{tabular}

Explanations see Table 3.

Zybert et al. (2015) in their studies on mass raw material studied the influence of slaughtering season on basic slaughter characteristics. They reported a statistically significant effect of slaughter season on hot carcass weight, meatiness, back fat thickness measured at $S_{1}$ and $S_{2}$, and LD muscle thickness at points $M_{1}$ and $M_{2}$. In their study, it was found that heavier pigs were slaughtered during the winter and spring, and the lightest ones in the summer. The authors also found the highest percentage $(69.4 \%)$ of the most valuable carcasses (classes $\mathrm{S}$ and $\mathrm{E}$ ) in fatteners weighing no more than $76 \mathrm{~kg}$ in winter. Antosik et al. (2010), in studies on fatteners from the mass population, found a statistically significant influence of season on hot carcass weight, meatiness, back fat thickness measured at point $\mathrm{S}_{2}$ and LD thickness at point $\mathrm{M}_{1}$. Pigs slaughtered in autumn had the highest meat content of $58.50 \%$, the thinnest back fat at $11.55 \mathrm{~mm}$ and the thickest LD muscle measured at $\mathrm{M}_{1}(62.24 \mathrm{~mm})$ compared to the remaining seasons of spring, summer and winter. In turn, hot carcass weight was uniform in the autumn and winter seasons in relation to the spring and summer seasons (winter - $86.6 \mathrm{~kg}$, autumn $-85.65 \mathrm{~kg}$, against spring $-83.40 \mathrm{~kg}$ and summer $-84.2 \mathrm{~kg}$ ). Gardzińska et al. (2002), in studies on landrace x (duroc x pietrain) crossbred fatteners, found a significant decrease in the meatiness and a significant increase in back fat thickness of pigs whose weight on slaughter day exceeded $120 \mathrm{~kg}$ compared to fatteners of lower weights.

\section{CONCLUSIONS}

The analyzed population of Polish Landrace fatteners had high meatiness (average level of $58 \%$ ), and high average hot carcass weight (about $90 \mathrm{~kg}$ ). All analyzed carcasses were classified as the highest meat classes: S, E and U. The influence of supplier on hot carcass 
weight, LD thickness at $\mathrm{M}_{1}$, and slaughtering efficiency; and the influence of the season on hot carcass weight and back fat thickness at points $S_{1}$ and $S_{2}$ were found to be statistically significant. Pigs slaughtered in spring had a lower hot carcass weight and thinner back fat compared to those slaughtered in autumn. The interaction of supplier and season was also found to have a statistically significant influence on hot carcass weight, meatiness, back fat thickness measured at $S_{1}$, and LD muscle thickness at $M_{2}$. The obtained research results indicate the high slaughter value of porkers kept in individual farms within the same producer group, and the pork obtained from these pigs meets the requirements set by the meat industry and consumers.

\section{REFERENCES}

Andersen H.J., Oksbjerg N., Young J.F., Therkildsen M. 2005. Feeding and meat quality - a future approach. Meat Sci. 70(3), 543-554.

Antosik K., Koćwin-Podsiadła M. 2010. Analiza zależności między masą tuszy ciepłej a mięsnością tusz tuczników w pogłowiu masowym [Analysis of the relationship between the weight of a hot carcass and the meatiness of carcasses in mass population]. Rocz. Nauk. PTZ 6(4), 259-268. [in Polish]

Antosik K., Koćwin-Podsiadła M., Kudelska A. 2010. Związek mięsności z cechami jakości tuszy tuczników pogłowia masowego, szacowanymi aparatem ULTRA FOM 300, z uwzględnieniem sezonu uboju [The relationship between meatiness and the qualities of the carcass fattening pigs, estimated ULTRA FOM 300 apparatus]. Rocz. Nauk. PTZ 6(4), 269-276. [in Polish]

Blicharski T., Kurył J., Pierzchała M. 2004. Zależność między polimorfizmem loci kolipazy i leptyny z najważniejszymi cechami użytkowości tucznej i rzeźnej świń ze szczególnym uwzględnieniem poziomu tłuszczu śródmięśniowego [The relationship between polymorphism loci colipase and leptin with the most important features of fattening and slaughter pigs with special emphasis on the level of intramuscular fat]. Pr. Mater. Zoot., 15(zesz. spec), 41-46. [in Polish]

Borzuta K. 1998. Badania nad przydatnością różnych metod szacowania mięsności do klasyfikacji tusz wieprzowych w systemie EUROP [Research on the usefulness of various methods for estimating meatiness for the classification of pig carcases in the EUROP system]. Rocz. Inst. Przem. Mięs. Tłuszcz. 35(2), 1. [in Polish]

Dumas J., Dhorne T. 1998. Pig carcass grading in Europen Union. 44th ICOMST, Barcelona, [b.w.], 946-947.

Florek M., Litwińczuk A., Skałecki P., Kędzierska-Matysek M., Grodzicki T. 2006. Udział elementów zasadniczych w tuszach wieprzowych w zależności od klasy EUROP i ubojowej masy tuczników [Share of basic elements in pig carcasses depending on the EUROP class and the slaughter weight of fattening pigs]. Rocz. Nauk. PTZ 2(4), 87-95. [in Polish]

Gardzińska A., Migdał W., Wantuła M., Stawarz M. 2002. Wartość tuczna i rzeźna tuczników pbz x (duroc $x$ pietrain) o różnej masie ciała $w$ dniu uboju [Mast and slaughter value of fattening pigs polish landarce $x$ (duroc $x$ pietrain) with different body weights on the day of slaughter]. Pr. Mater. Zoot. 13, 49-53. [in Polish]

Główny Urząd Statystyczny. 2017. Pogłowie trzody chlewnej w 2016 roku. Warszawa, GUS. [in Polish]

Grześkowiak E. 1999. Technologiczna i konsumpcyjna przydatność mięsa krzyżówek towarowych świń polskich ras białych z udziałem knurów ras Hampshire i Duroc. Rozprawa habilitacyjna, Szczecin, AR w Szczecinie. [in Polish]

Koćwin-Podsiadła M., Zybert A., Sieczkowska H., Krzęcio E., Antosik K., Włodawiec P. 2004. Muscling and carcass composition in fatteners obtained from $\mathrm{F}$ generation imported from Denmark. Anim. Sci. Pap. Rep. 22, 3(Suppl.), 147-151. 
Lisiak D., Borzuta K. 2008. Zmiany wartości rzeźnej oraz cen tusz wieprzowych w I półroczu lat 2003-2008. [Changes in the slaughter value and pig carcass prices in the first half of 2003-2008]. Trzoda Chlew. 12, 42-43. [in Polish]

Lisiak D., Pater A., Borzuta K. 2005. Wartość rzeźna tusz wieprzowych i ceny wybranych wyrobów mięsnych [Slaughter value of pig carcasses and prices of selected meat products]. Gosp. Mięs. 57(9), 50-53. [in Polish]

Lisiak D., Janiszewski P., Slósarz P. 2016. Wartościowanie tusz wieprzowych z pominięciem klasyfikacji SEUROP, w: LXXXI Zjazd Naukowy Polskiego Towarzystwa Zootechnicznego „Innowacyjność nauk o zwierzętach w XXI wieku”, Warszawa 21-23.09.2016, [b.w.]. [in Polish]

Luszniewicz A., Słaby T. 2001. Statystyka. Teoria i zadania. Warszawa, Wydaw. C.H. Beck. [in Polish]

Kyczyński A, Pośpiech E., Urbaniak M., Frankiewicz S. 2000. Cechy rzeźne świń ubijanych przy równej masie ciała [Traits of slaughtered pigs at equal body weight]. Rocz. Nauk. Zoot. 6 , 181-185. [in Polish]

Różycki M. 1998. Możliwości poprawy jakości mięsa świń hodowlanych w Polsce na drodze selekcji [Possibilities of improving the quality of meat of breeding pigs in Poland by means of selection]. Pr. Mater. Zoot. 8(zesz. spec.), 19-25. [in Polish]

Strzelecki J., Borzuta K., Kien S., Lisiak D. 2001. Wartość rzeźna i jakość mięsa tuczników o różnej mięsności [Slaughter value and quality of meat for fattening pigs with different meatiness]. Rocz. Inst. Przem. Mięs. Tłuszcz. 38, 31-40. [in Polish]

Vandendriessche F. 2008. Meat products in the past, today and in the future. Meat Sci. 78(1-2), 104-113.

Weatherup R.N., Beattie V.E., Moss B.W., Kilpatrick D.J., Walker N. 1998. The effect of increasing slaughter weight on the production performance and meat quality of finishing pigs. Anim. Sci. 67(3), 591-600.

Wood J.D., Wiseman J., Cole D.J.A. 1994. Control and manipulation of meat quality, in: Principles of Pig Science, Nottingham University Press, 433-456.

Zybert A., Koćwin-Podsiadła M., Krzęcio E. 2001. The influence of hot carcass weight on quantitative traits and lean meat content estimated according to method used in polish pig testing stations. Pol. J. Food Nutr. Sci. 10(51), 3, 252-264.

Zybert A., Koćwin-Podsiadła M., Krzęcio E., Sieczkowska H., Antosik K. 2005. Uzysk i procentowy udział masy mięsa i tłuszczu ogółem w półtuszy pozyskanych z rozbioru i wykrawania tusz wieprzowych zróżnicowanych masą oraz klasą mięsności według systemu klasyfikacji EUROP [The yield and percentage share of the total meat and fat mass in half-carcasses obtained from cutting and punching of pork carcasses varied by weight and meat class according to the EUROP classification system]. Żywn. Nauka Techn. Jakość 3(44), 254-263. [in Polish]

Zybert A., Tarczyński K., Sieczkowska H., Koćwin-Podsiadła M., Iwan R. 2015. Wpływ pory roku wykonania uboju i masy tuszy ciepłej na mięsność tuczników pogłowia masowego [Influence of the season of slaughtering and the weight of the hot carcass on the meatiness of fatteners in the mass population]. Rocz. Nauk. PTZ 11(2), 57-67. [in Polish]

\section{WARTOŚĆ RZEŹNA TUCZNIKÓW RASY POLSKIEJ BIAŁEJ ZWISŁOUCHEJ POCHODZĄCYCH Z GOSPODARSTW ŚRODKOWO-WSCHODNIEJ POLSKI}

Streszczenie. Celem niniejszej pracy jest ocena wartości rzeźnej tuczników pochodzących $z$ indywidualnych gospodarstw rolnych zrzeszonych $w$ grupie producenckiej zlokalizowanej w środkowo-wschodniej Polsce. Badania przeprowadzono na 322 tucznikach rasy polskiej białej zwisłouchej (PBZ). Materiał doświadczalny sklasyfikowano, uwzględniając 2 czynniki badawcze: dostawcę i porę roku. Tuczniki z I grupy badawczej ubijano na jesieni w miesiącach wrzesień-październik, a tuczniki z II grupy badawczej - wiosną w miesiącach kwiecień-maj. Badana populacja tuczników charakteryzowała się wysoką mięsnością - na poziomie $58 \%$ oraz masą 
tuszy ciepłej $89,99 \mathrm{~kg}$. Wszystkie tusze tuczników zostały zakwalifikowane do najwyższych klas w systemie SEUROP - odpowiednio: $29,81 \%$ do klasy S, $51,86 \%$ do klasy E i $18,32 \%$ do klasy U. Udowodniono statystycznie wpływ dostawcy na masę tuszy ciepłej, grubość mięśnia longissimus dorsi w punkcie $\mathrm{M}_{1}$, wydajność rzeźną oraz wpływ sezonu uboju na masę tuszy ciepłej i grubość słoniny w punktach $S_{1}$ i $S_{2}$. W wyniku przeprowadzonych badań stwierdzono, że tuczniki, których uboju dokonano wiosną, odznaczały się mniejszą masą tuszy ciepłej i cieńszą słoniną. Wykazano współdziałanie obydwu czynników badawczych, tj. dostawcy surowca rzeźnego i sezonu uboju, w przypadku masy tuszy ciepłej, mięsności, mięśnia LD mierzonego w punkcie $M_{2}$, grubości słoniny mierzonej w punkcie $S_{1}$. Otrzymane wyniki badań wskazują na dużą wartość rzeźną tuczników utrzymywanych $w$ indywidualnych gospodarstwach rolnych zrzeszonych w grupy producenckie; wieprzowina pozyskana od tych świń spełnia wymagania stawiane przez przemysł mięsny i konsumentów.

Słowa kluczowe: tuczniki, dostawca, sezon, mięsność, masa tuszy ciepłej. 
